Available online on 15.03.2020 at http://jddtonline.info
Open Access to Pharmaceutical and Medical Research
unrestricted non-commercial use, provided the original work is properly cited

Open $\odot$ Access

Research Article

\title{
Antitoxic, Antifungal and Phytochemical Analysis of Medicinal Compounds of Guiera senegalensis Leaves
}

\author{
Z.M. Anka ${ }^{*}$, Vijender Singh ${ }^{1}$, S.N. Gimba ${ }^{2}$, Gunjan Singh1 \\ ${ }^{1}$ Department of Pharmacy, School of Allied Health Science, Sharda University, Greater Noida U.P, India \\ 2 School of General Studies, Shehu Sule College of Nursing and Midwifery, Damaturu, Yobe State, Nigeria
}

\begin{abstract}
Millions of people in the world depend on traditional medicinal plants for treatment of many diseases. They have curative properties due to presence of various complex chemical substances of different composition, which are found as secondary plant metabolites in one or more parts of these plants. These plant metabolites according to their composition are grouped as flavonoids, tannins, alkaloids, saponins etc. Guiera senegalensis(Gs), which grows in abundance in semi-desert area of Western Africa such as Nigeria, has been used for treating specific diseases and wounds. The study is carried out to investigate the phytochemical analysis, toxicity, and the antifungal activity of Gs leaves extract.
\end{abstract}

Keywords: Guiera senegalensis, Antifungal activity, Brine shrimp, toxicity, phytochemical analysis;

Article Info: Received 09 Jan 2020; Review Completed 21 Feb 2020; Accepted 29 Feb 2020; Available online 15 March 2020

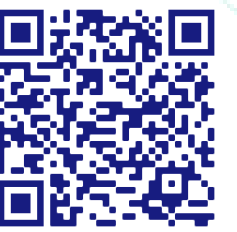

\section{Cite this article as:}

Anka ZM, Singh V, Gimba SN, Singh G, Antitoxic, Antifungal and Phytochemical Analysis of Medicinal Compounds of Guiera senegalensis Leaves, Journal of Drug Delivery and Therapeutics. 2020; 10(2):148-152 http://dx.doi.org/10.22270/jddt.v10i2.3932

*Address for Correspondence:

S.N. GIMBA School of General Studies, Shehu Sule College of Nursing and Midwifery, Damaturu, Yobe State, Nigeria

\section{INTRODUCTION}

Guiera senegalensis is called Sabara" (Hausa), [1]. It is a shrubby and can grow to a height of 3 to $5 \mathrm{~m}$ depending on the habitat [2]. The leaves which are 3 to $5 \mathrm{~cm}$ long and 1.5 to $3.0 \mathrm{~cm}$ broad are arranged opposite or sub opposite on the stem [3]. It is widely distributed in the savannah region of west and central Africa, Nigeria, Senegal, Gambia, Mali, Niger, Burkina Faso and Ghana, [4-6]. It is active against cough, respiratory congestion and fever [7,8], and is prescribed as an antitusive, hypertension and hypotension as well as venereal diseases [7], to ease breathing and to treat lung and bronchial disorders. It is also used against malaria fever [9].

\section{Botanical Description}

Kingdom: Plantae, Division: Magnoliophyta, Class:

Magnoliopsida, Order: Myrtales, Family: Combretaceae,

Genus: Guiera Species: senegalensis

\section{Morphology}

Guiera senegalensis, very well known in its native area, generally occurs as a shrub that can grow to a height of 3 to $5 \mathrm{~m}$ according to habitat. Its stem presents numerous knots that send out branches. The ash-grey stem and branches have fibrous or pubescent bark and bear opposing, short petiolated oval leaves, sometimes mucronate, sometimes even cordate at their base, about 2 to $4 \mathrm{~cm}$ long by 1 to $2 \mathrm{~cm}$ wide. These grey-green leaves, darker on their upper surface, display black spots on their lower surface and are slightly downy on both sides. These features lend the plant an overall silver green color that is conspicuous in brushland [2]. Flowering occurs almost throughout the year, when it is leafy. Often blooms twice a year, during the dry season and the rainy season. Each flower has a calcinal tube ovoid, welded to the ovary. This tube is topped by a bellflower blade with 5 teeth screened black and persistent points to fruiting. The ligulform corolla is composed of 5 petals also riddled with black spots. The stamens are 10 on two rows of 5 , all inserted on the calyx. The ovary has a single box containing 4 to 6 eggs [11].

\section{Habitat and Repartition}

It is a plant that grows primarily in Sudanian Sahel area, on soils sandy, leached or exhausted, fallow and dry stations. Plant pioneer disseminated by cattle in the fallow land, it is also indicative of overgrazing. It is found from Nigeria, Senegal to Cameroon to Sudan. Widespread and common, locally gregarious and very abundant [12] 


\section{METHODOLOGY}

\section{Plant materials}

The leaves of $G s$ used in this study were randomly collected from $G$ s bushes around Bakura village area of Zamfara State, Nigeria. The plant leaves were dried in the shade. After drying, the leaves were ground well into fine powder using mechanical blender, and the powder was transferred into airtight containers with proper labeling for future use.

\section{Water extraction}

Five grams of the plant powder was placed in a beaker containing $100 \mathrm{ml}$. distilled water; soaked and shaken well. The solution was filtered with the help of filter paper and the filtrate was kept and used for further phytochemical analysis. The extracts were then kept in sterile bottles, under refrigerated conditions, until further use.

\section{Phytochemistry}

Earlier works showed that leaves and roots of G. senegalensis contained Harman, tetrahydroharman, harmalan and Guieranone A [1]. The plant has been found to contain carbohydrates, steroids, flavonoids, saponins, alkaloids, tannins and mucilage [24, 26]. Ficarra et al. in 1997 found four flavonoids in the leaves of G. senegalensis, namely catechin, myricitrin, rutin and querterin [13].

Some findings on the plant elsewhere showed the presence of alkaloids (Hyoscyamin [I] and solanine, [II]), tannins, terpenoids menthol, coumarins, saponins, flavonoids (quercetin,[III]), cardiotonics and cyanogenic heterosides which were assayed in various organs of the plant leaves, stem bark, fruits and roots [12]. Hyoscyamin [I], solanine [II] and quercetin [III] are represented in figure 2. While in the gall of the plant from Ouagadougou, Burkina Faso, alkaloids, polyphenols and saponins were detected [23]. The ashes are poor in alkali but rich in alkaline earth metals. We found especially $\mathrm{Mg}, \mathrm{Ca}, \mathrm{Sr}, \mathrm{Ti}, \mathrm{Fe}, \mathrm{Al}$ and in lesser amounts sometimes traces: $\mathrm{Cu}, \mathrm{Ni}, \mathrm{Co}, \mathrm{Zn}$ [11]. Previous studies indicated the presence in leaves of two alkaloids (harman, tetrahydroharman or eleagnine), flavonoids, naphthopyrans, tannins, and a naphthyl butenone (guieranone A); in roots, were only obtained tannins and the same betacarboline alkaloids than in leaves [9, 11, 29, 30, 31, 32, 33]

\section{Antifungal test}

Antimicrobial activity testing was carried out by using agar spread method. One ml of the Gs extract (5\%) was spread to each one of seven (PDA) that were cultured with Stemphylium solani, Aspergillus flavus, Trichoderma viride, Penicillium spp, Fusarium ver ticillatum, Cladosporium cladosporioides, Fusarium solani. The petri dishes were incubated for seven days at room temperature. At the end of incubation, zone of inhibition that developed were measured with a ruler. Distilled water was used as a control.

\section{Test for flavonoids}

For the confirmation of flavonoids in the Gs leave powder, $0.5 \mathrm{~g}$ of plant extract was placed in a test tube and $10 \mathrm{ml}$ of distill water was added, $5 \mathrm{ml}$ of dilute ammonia solution were added to a portion of the aqueous filtrate of the plant extract followed by addition of $1 \mathrm{ml}$ concentrated H2SO4. Indication of a yellow color shows the presence of flavonoids in each extract [34].

\section{Test for Alkaloids}

The procedure used for determination of alkalolids in Gs sample is similar to that described by [34]. Briefly, $0.2 \mathrm{~g}$ of $G s$ leave powder was added to a glass test tube that has $3 \mathrm{ml}$ of hexane. The powder and hexane were thoroughly mixed, shaken well, and filtered. To the hexane and Gs leaves extract mixture, $5 \mathrm{ml}$ of $2 \% \mathrm{HCl}$ were added, and the mixture heated until boiling. The mixture was then filtered, and 1-3 drops of picric acid were added to the hexane, $\mathrm{HCl}$ and Gs leave extract filtrate. The presence of alkaloids in the Gs sample was confirmed by the yellow- colored precipitate that was formed.

\section{Test for Terpenoids}

An amount of 0.8 gram of the $G s$ leave powder was placed in a test tube, then $10 \mathrm{ml}$. of methanol was poured in it, shaken well and filtered. Five $\mathrm{ml}$ of the plant extract of plant sample was taken. Then $2 \mathrm{ml}$ of chloroform were mixed with the extract and $3 \mathrm{ml}$ of sulphuric acid were added. Formation of reddish brown color indicates the presence of terpenoids in the selected plants [34].

\section{Test for Tannins}

Crude extract of Gs powder was mixed with $2 \mathrm{ml}$ of $2 \%$ solution of FeCl3. A blue-green or black coloration indicated the presence of tannins [35].

\section{Test for proteins, ninhydrin test}

The Crude extract of $G S$ leaves powder was boiled with $2 \mathrm{ml}$ of $0.2 \%$ solution of Ninhydrin. Violet color appearance will suggest the presence of amino acids and proteins [35].

\section{Test for Carbohydrates, Fehling's test}

Two ml. of equal volumes of Fehling A and Fehling B reagents mixed together were added to the crude extract and gently boiled. A brick red precipitate appearing at the bottom of the test tube indicates the presence of reducing sugars [35].

\section{Test for Steroids}

Gs leaves powder was mixed with $2 \mathrm{ml}$ of chloroform and concentrated $\mathrm{H} 2 \mathrm{SO} 4$ was added sidewise. A red colour produced in the lower chloroform layer indicated the presence of steroids. Another test was performed by mixing crude extract with $2 \mathrm{ml}$ of chloroform. Then $2 \mathrm{ml}$ of each of concentrated $\mathrm{H} 2 \mathrm{SO} 4$ and acetic acid were poured into the mixture. The development of a greenish coloration indicated the presence of steroids [35].

\section{Test for Saponins}

The crude extract was mixed with $5 \mathrm{ml}$ of distilled water in a test tube and it was shaken vigorously. The formation of stable foam was taken as an indication for the presence of saponins [35].

\section{RESULTS AND DISCUSSION}

\section{Toxicity test}

In the present study, brine shrimp (artemia) toxicity test was used to find out if the leaves extract is safe to consume. The artemia toxicity test is used routinely because it is convenient to use in addition to being inexpensive. As a routine test, it is employed as an initial step in the assessment and evaluation of the toxic characteristics of a substance [36], for screening drugs, and for determination of lethal doses, and for assessing health hazards that may arise from short term exposure to drugs [37]. On these grounds, we decided to use the brine shrimp (artemia) toxicity test to evaluate if the traditional medicinal plants Gs leave extract has potential toxicity. In the present study, the leave extracts from Gs showed no toxicity to brine shrimps at concentrations of 250,500, and $1000 \mu \mathrm{g}$ in $40 \mathrm{ml}$ of distilled water, and that was confirmed by the number of dead brine 
shrimp larvae, which was zero. From this result, we can conclude that the Gs leaves extract is apparently not toxic. Our result are in general agreement with that obtained by Ref. [37] who observed that water extract of Gs given at the rate of $2 \mathrm{~g} / \mathrm{kg}$ to Wister male and female rats showed no toxicity as confirmed by the evaluation of pathological changes in different organs, hematological parameters, and urinalysis. The results of the present study are also in agreement with Ref. [38] who concluded that Gs aqueous leave extract is not toxic and may be safe, especially at the dose used for treatment, which is greatly lower than the doses used in their experiments. However, the findings of the present study are not in agreement with that found by Ref. [39] who reported signs of toxicity when experimental animals were drenched with the leaves powder of Gs. At the dosage of 1 or $2 \mathrm{~g} / \mathrm{k} /$ day, this disagreement could be explained by the fact that the present study used the aqueous extract of the leaves while Ref. [39] used the actual leaves powder. Interestingly, Ref. [39] observed that the treated animals became drowsy suggesting an effect of $G s$ powder on the cardiovascular system function and blood pressure. This may explain the folk use of the plant for hypertension control. Further, Ref. [40] reported that spontaneous motor activity was decreased in mice by administration of the aqueous extract of $G s$, and that the sleeping time induced by pentobarbital was prolonged in treated mice.

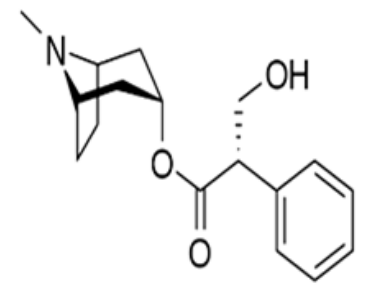

[I] Hyoscyamine

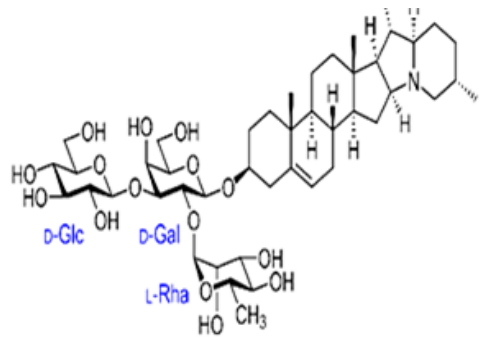

[II] Solanine<smiles>O=c1c(O)c(-c2ccc(O)c(O)c2)oc2cc(O)cc(O)c12</smiles>

[III] Quercetin

Fig 2:Chemical structure from Guiera senegalensis [34].

\begin{abstract}
Antifungal activity
In developing countries, medicinal plants are gaining popularity because of their perceived effects against microbes, and cost or invariability of health care. The World Health Organization (WHO) reported that approximately $80 \%$ of the world population use traditional medicinal plants the extracts or the active ingredients in medicinal plants [41]. On the other hand, more than $60 \%$ of the successful drugs developed against infections during the last twenty years utilized natural products [42]. Therefore, the interest in traditional medicinal plants will continue to grow as emerging infectious diseases continue to expand, and the numbers of drug resistant microbes continue to escalate. Further, plant extract are often consumed without paying attention to safety issues. In the present work, the antimicrobial activity of the extracts of $G s$ was studied against seven fungal strains. For the antifungal susceptibility test, the leaves extracts obtained from Gs showed no activity (No inhibition) against all of the tested fungal strain. Ref. [43] indicated that since solvents used for extraction are expected to have different range of solubility for the phytochemical component of the medicinal plant, ethanolic extract would be more effective in treatment than an aqueous extract. In Western Sudan, people use the aqueous extract of the leaves as a medicine. However, from drug discovery point of view, it would be interesting to quantify antimicrobial activity of $G s$ ingredients extracted using ethanolic solvent in which plant material is expected to dissolve better.
\end{abstract}

\section{Phytochemical analysis}

This study also showed the presence of different phytochemicals whose biological activity can be of valuable therapeutic index. The result of the presence of the phytochemicals in Gs extract, shown in Table 1, is indicated by the colour intensity in a scale of $4(+,++,+++,++++)$.

Since medicinal plants, such as Gs, are expected to be a valuable source for a variety of drugs, no wonder that $80 \%$ of individuals from developed countries use traditional medicines extracted from plants according to W.H.O [41]. Therefore, is important to investigate traditional medicinal plants to assess their properties, safety, and efficacy of treatment, and the optimum dose [44]. Table 1. Shows that plant under investigation contains flavonoids, alkaloids, terpenoids, tannin, proteins, carbohydrates, steroids and saponins, Our result is in line with the findings obtained by Ref. [45] who indicated that Gs leave extract had been found to contain alkaloids, tannins, flavonoids, amino acids, in addition to its antimicrobial activity. The results of the present study also agrees with that reported by Ref. [46] who also confirmed the presence in Gs leave extract of flavonoids, saponins, tannins, terpenes, and carbohydrates. One of ingredients that we found in Gs leave extract are terpenoids, which are found to have a variety of pharmacological activities such anti-bacterial, antiinflammatory and anti-malarial activities [47, 48]. The presence of flavonoids in Gs leaves extract documented in this study supports the findings of Ref. [49] who stated that the antimicrobial properties in some traditional medicinal plants can be due to the presence of flavonoids. Furthermore, several biological effects such as antioxidants abilities, and anti-inflammatory effects are attributed to flavonoids and phenolic compounds in medicinal plants [50]. These observations and the findings of the present study suggest there is an urgent need to investigate why Gs extract is credited for curing several diseases and infections in Africa. It would be important to find out which phytochemical compound in $G s$ is responsible for what activity.

The content of alkaloids, tannin and saponins found in the present study agree with that reported by Ref. [51] who reported high levels of alkaloids and low tannins and saponins content in Gs. Alkaloids found in medicinal plants used as anesthetic agents [52], a premise that was not investigated in the present study. In addition, tannins have been found by Ref. [53] to have a wide range of antimicrobial and anti-inflammatory effects. The anti-carcinogenic 
potentials of tannins could be attributed to its anti-oxidative properties that protect living cells from oxidative damage [54]. It is documented in this study that steroids were present in Gs leave extract. These steroids have antibacterial effects [55], and are important because of its relationship with steroid hormones such as sex hormones estrogen and testosterone [56].

The observed antibacterial effects of the medicinal plants extracts have been related to the presence of tannins, flavonoids and saponins [57]. This is in agreement with Ref. [58] who investigated the effect Eucalyptus Camaldulensis extract against pathogenic bacteria (Salmonella typhi and Escherichia coli) and attributed the effect of the plant extract to the active phytochemical compounds it has, namely tannins, flavonoids and saponins. Gs have been shown to contain compounds such as alkaloids, tannins, flavonoids that demonstrated their antimicrobial activity [59].

\section{Traditional Uses}

G. senegalensis is considered by traditional practitioners of Nigeria, Burkina Faso, Senegal, and Mali as a panacea, both its medicinal properties are significant and varied. The usual form of preparation for internal use is in decoction or mixed with food preparations. G. senegalensis leaves are widely administered for pulmonary and respiratory complaints, for coughs, as a febrifuge, colic and diarrhea, syphilis, beriberi, leprosy, impotence, rheumatism, diuresis and expurgation $[60,61]$.

\section{Pharmacological and Toxicological Activities}

Guiera senegalensis is a popular medicinal plant for both human and veterinary use in West Africa. It's leaves have been reportedly used to treat rhinitis, bronchitis and fever, and the roots to treat diarrhea and dysentery. It is recognized as being active against cough, respiratory congestion and fever [14], and is prescribed as an antitussive $[11,15,16,17,18]$, to ease breathing and to treat lung and bronchial disorders. It is also used against malaria $[9,19,20]$. The syrup D2 from G. senegalensis has been screened for its antitussive clinical essay [10]. Aqueous extracts from its roots and leaves have also been screened for toxicity [21]. The galls of G. senegalensis are used in Burkina Faso as an ethnoveterinary product to increase milk production in cows and to treat fowlpox infection in chickens [22]. Guiera senegalensis leaves extract or fractions may be used for the treatment of various disease caused by Escherichia coli, Pseudomonas aeruginosa and Klebsiella pneumonia [24]. View in toxicity, aqueous extracts are overall low toxicity; "extract of leaves being slightly more active than the extract from roots in the Guinea pig, rabbit, dog and less active in mice and rats [11]. G. Senegalensis at lower doses is not harmful to the liver and therefore can be exploited as it is served in the treatments of some illnesses [25]. Treatment with water and methanol extracts from G. senegalensis leaves resulted in endotheliotoxicity, hepatonephropathy and pancreatic hyperplasia [27]. Guieranone A from Guiera senegalensis showed a strong antiplasmodial activity associated with a high cytotoxicity toward human monocytes [1]. Methanol fraction from leaves extract only had antiplasmodial activity [28].

\section{CONCLUSION}

In conclusion, medicinal plants are used for discovering and screening of the phytochemical constituents which are very helpful for the manufacturing of new drugs for treatment of various diseases. The results obtained in the present study have shown that Gs leaves have high concentration of alkaloids and low concentration of tannins and saponins and have no toxic effect and show no antimicrobial activities in case of fungi. These observations and the findings of the present study suggest an urgent need for investigating why Gs extract is credited for curing several disease and infections in Africa. It would be of important to find out which phytochemical compound in $G s$ is responsible for what activity. Thus, we hope that the important phytochemical compounds identified by our study in the Gs, will be helpful in treating different diseases of this particular region of Africa, and may be in other regions. The plant extract may be safe, especially at the therapeutic dose which is far lower than the tested doses. The results could serve for further pharmacological and phytochemical research. Also more research needed to evaluate the potential effectiveness of the crude extracts as the antimicrobial agents.

\section{REFERENCES}

1. Fiot J, Sanon S, Azas N, et al. Phytochemical and pharmacological study of roots and leaves of Guiera senegalensis J.F. Gmel (Combretaceae). Journal of ethnopharmacology 2006; 106(2):173-178.

2. Silva O, Serrano R, Gomes ET. Botanical characterization of Guiera senegalensis leaves. Microscopy and Microanalysis. Official journal of microscopy society of America 2008; 14(5):398-404.

3. Hutchinson J, Dalziel JM. Flora of West Tropical Africa. London: Crown Agents, 1972.

4. Zeljan M, Marica M, Franz B. Flavonoida of G. senegalensisThin layer Chromatography and Numerical Methods. Croatica Chemica Acta 1998; 71(1):69-79.

5. Shettima YA, Tijjani MA, Kanumi Y, et al. Phytochemical and antidiarrhoeal properties of methanol extract of Guiera senegalensis J.F. Gmel International Journal of Pharmacy, 2012; 3(11).

6. Tijjani A, Sallau MS, Sunusi I. Synergistic activity of methanolic extract of Adenium obesum (Apocynaceae) stem-bark and xytetracycline against some clinical bacterial isolates. Bayero Journal of Pure and Applied Sciences 2011; 4(1):79-82.

7. Adedapo AA, Sofidiya MO, Afolayan AJ. Antiinflammatory and analgesic activities of the aqueous extracts of Margaritaria discoidea (Euphorbiaceae) stem bark in experimental animal models. (Int J Trop Biol. 2009; 57(4):1193-1200.

8. Ali AJ, Akanya HO, Dauda BEN, et al. Antiplasmodial, analgesic and anti-inflammatory effects of crude Guiera senegalensis J.F. Gmel (Combretaceae) leaf extracts in mice infected with Plasmodium berghei. Journal of Pharmacognosy and Phytotherapy, 2011, 3(10).

9. Ancolio C, Azas N, Mahiou V, et al. Antimalarial activity of extracts and alkaloids isolated from six plants used in traditional medicine in Mali and Sao Tome. Phytotheraphy Research. 2002; 16(7):646-649.

10. Dénou A. Contribution à l'étude des problèmes de conservation de la forme sirop des médicaments traditionnels. Thèse de Pharmacie, FMPOS, Bamako. 2008, 82p.

11. Koumaré M. Contribution à l'étude pharmacologique du Guiera senegalensis Lam, Combretaceae. Thèse de Doctorat en pharmacie, Toulouse-France, 1968.

12. Somboro A A, Patel K, Diallo D, Sidibe L, Chalchat JC, Figueredo G, Ducki S, Troin Y, Chalard P. An ethnobotanical and phytochemical study of the African medicinal plant Guiera senegalensis J. F. Gmel. Journal of Medicinal Plants Research. 2011; 5(9):1639-1651.

13. Ficarra R, Ficarra P, Tommasini S, Carulli M, Melardi S, Di Bella MR, Calabro ML, De Pasquale R, Germano MP, Sanogo R, Casuscelli. Isolation characterization of Guiera senegalensis J. F.Gmel., active principales. Boll. Chim. Farm. 1997; 136(5):454-459.

14. Kerharo J, Adam JG. La Pharmacopée Sénégalaise Traditionnelle. Plantes Médicinales et Toxiques. Editions Vigot Frères, Paris. 1974, p. 1011.

15. Negrevergne G. New medicament based on a dry aqueous extract of Guiera senegalensis, especially useful as a hypotensive and antitussive agent. Fr. M. 1968, p. 2

16. Faye 0, Olschwamg D, Giono-Barber H, Pousset JL. Action antitussive d'un extrait lyophilisé de Guiera senegalensis. Plantes médicinales Africaines II, 1980; 25(4):285-292. 
17. Sanogo R, De Pasquale R, Germano MP. The Antitussive Activity of Guiera senegalensis J. F. Gmel. (Combretaceae) Phytother. Res., 1998; 12(2):132-134

18. Diatta W, Fall AD, Dieye AM, Faty S, Bassene E, Faye B. Experimental evidence of cough activity of total alkaloids from Guiera senegalensis Lam., In guinea pig. Dakar Med., 2007; 52(2):130-134.

19. Benoit F, Valentin A, Pelissier Y, Diafouka F, Marion C, KoneBamba D, Kone M, Mallie M, Yapo A, Bastide JM . In vitro antimalarial activity of vegetal extracts used in West African traditional medicine. Am. J. Trop. Med. Hyg., 1996; 54(1):6771.

20. Azas N, Laurencin N, Delmas F, Di Giorgio C, Gasquet M, Laget $\mathrm{M}$, Timon-David $\mathrm{P}$, Synergistic in vitro antimalarial activity of plant extracts used as traditional herbal remedies in Mali. Parasitol. Res., 2002; 88(2):165-171.

21. Pousset JL. Plantes médicinales africaines: Utilisation pratiques. Paris: Ellipses- ACCT. 1989.

22. Nacoulma OG. Plantes médicinales et pratiques médicales traditionnelles au Burkina Faso. Cas du plateau central. Tome2. Ph.D. thesis, University of Ouagadougou. 1996.

23. Lamien CE, Meda A, Couacy-Hymann E, et al. The phytochemical composition and in vitro antiviral activity of decoctions from galls of Guiera senegalensis J.F. Gmel. (Combretaceae) and their relative non-toxicity for chickens. Onderstepoort Journal of Veterinary Research 2005; 72:111118.

24. Salihu SO, Usman AA. Antimicrobial and phytochemical study of the bioactive fractions of Guiera senegalensis from Alasan Tambuwal, Nigeria. Journal of Pharmacognosy and Phytochemistry 2015; 3(6):106-111.

25. Oshobu MA, Geidam MA. Effects of Aqueous Ethanolic Extract of the leaves of Guiera senegalensis J.F. Gmel (Combretaceae) on Liver Function in Wister Strain Albino Rats. International Journal of scientific research and management (IJSRM); 2014; 2(3):611-615.

26. Mohammed SY. Quantitative phytochemical and elemental analysis of Guiera senegalensis leaf extract. Journal of Pharmacognosy and Phytotherapy. 2013,5(12), pp. 204-207.

27. Fatih Elrahman AO, Abuelgasim AI, Galal M. Toxicopathological effects of Guiera senegalensis extracts in wistar albino rats. Journal of Medicinal Plants Research. 2008; 2(1):001 - 004 .

28. Jigam AA, Akanya HO, Dauda BEN,. Ogbadoyi EO. Antiplasmodial, analgesic and anti-inflammatory effects of crude Guiera senegalensis Gmel (Combretaceae) leaf extracts in mice infected with Plasmodium berghei. Journal of Pharmacognosy and Phytotherapy. 2011; 3(10):150-154.

29. Bouchet N, Levesque J, Pousset J.L. HPLC isolation, identification andquantification of tannins from Guiera senegalensis. Phytochemical A nalysis. 2000,11, 52- 56.

30. Bucar F, Schubert-Zsilavecz M, Knauder E. Flavonoids of Guiera senegalensis. Pharmazie. 1996; 51:517-518.

31. Combier H, Becchi M, Cave A. Alcaloïdes du Guiera senegalensis Lam. Plantes Médicinales et Phytothérapie. 1977; 11:251-253.

32. Mahmoud EN, Sami AK,. 5-Methyldihydroflavasperone, a dihydronaphthopyran from Guiera senegalensis. Phytochemistry. 1997; 46:793-794.

33. Silva 0 , Gomes ET. Guieranone A, a naphthyl butenone from the leaves of Guiera Senegalensis with antifungal activity. Journal of Natural Products. 2003; 66:447-449.

34. Wadood A, Mehreen G, Syed BJ, Muhammad N, Ajmal K, et al. Phytochemical Analysis of Medicinal Plants Occurring in Local Area of Mardan. Biochem Anal Biochem 2013; 2:144.

35. Yadav RNS, Agarwala M, Phytochemical analysis of some medicinal plants. Journal of Phytology 2011; 3:2075-6240.

36. Tarzwell CM, Standard Methods for Determination of Relative Toxicity Of Oil Dispersants And Mixtures Of Dispersants And Various Oils To Aquatic Organisms. International Oil Spill Conference Proceedings 1969; 1:179-186.

37. Akhila JS, Deepa S, Alwar MC, Acute toxicity studies and determination of median lethal dose. Curr. Sci 2007; 93:917.

38. Diouf A, Cisse A, Gueye SS, Mendes V, Siby T, et al. Toxocological study of Guiera senegalensis Lam (Combretaceae). Dakar Med 2000; 45:89-94.
39. Hauwa'u YB, Maryam I, Ja'afaru SM, Maimuna Z, Timothy B, Toxicity studies of aqueous, methanolic and hexane leaf extracts of Guiera senegalensis in rats. International Journal of Scientific and Engineering Researchl 2014; 5:1339.

40. Ilham MO, Adam SEI, Mohammed AS, Toxicological Effects of Guiera senegalensis Family: Combrataceae on Nubian goats. The Sudan J Vet Res 2011; 26:65-70.

41. Amos S, Kolawole E, Akah P, Wambebe C, Gamaniel K, Behavioural effects of the aqueous extract of Guiera senegalensis in mice and rats. Phytomedicine 2001; 8:356361.

42. Shaik D, Malika FA, Rafi SM, Naqui B, Studies of antibacterial activity of ethanolic extract from Nericum indicum and Hibiscus rosasinensis. J Islamic Acad Sci 1994; 7:167-8.

43. Cragg GM, Newman DJ, Biodiversity: A continuing source of novel drug leads. Pure Appl Chem 2005; 77:7-24.

44. Srinivasan D, Perumalsamy LP, Nathan S, Sure T, Antimicrobial Activity of Certain Indian Medicinal Plants Used in Folkloric Medicine. Journal Ethnophatmacol 2001; 94:217-222.

45. Arunkumar S, Muthuselvam M, Analysis of phytochemical constituents and antimicrobial activities of aloevera L. against clinical pathogens. World J Agri Sc 2009; 5:572.

46. Sule AM, Thanni LOA, Sule OOA, Bacterial pathogens associated with infected wounds in Ogun State University Teaching Hospital, Sagamu, Nigeria. African Journal of Clinical and Experimental Microbiology 2002; 3:13-16.

47. Staden JV, Grobbelaar N, The effect of Sesbanimide and Sesbania seed extracts on germination and seedling growth of a number of plant species. Journal of Environmental and Experimental Botany 1995; 35:321-325.

48. Mahato SB, Sen S (1997) Advances in triterpenoid research 1990-1994. Phytochemistry 44: 1185-236.

49. Singh B, Bhat TK, Potential Therapeutic Applications of some Antinutritional Plant Secondary Metabolites. J Agric Food Chem 2003; 51:5579-5597.

50. Asha K, Rasika CT, Nirmala RD, Jyoti PS, Antioxidant Potentia from Stem Bark of Juglans regia L. Ann. Biol Res 2011; 2:176180.

51. Mohammed SY, Quantitative phytochemical and elemental analysis of Guiera senegalensis leaf extract. Journal of Pharmacognosy and Phytotherapy 2013; 5:204-207.

52. Hérouart D, Sangwan RS, Fliniaux MA, Sangwan NBS, Variations in the Leaf Alkaloid Content of Androgenic Diploid Plants of Datura innoxia. Planta Med 1988; 54:14-17.

53. Lata N, Dubey V, Preliminary phytochemical screening of Eichhornia crassipes: the world's worst aquatic weed. J of Pharmacy Research 2010; 3:1240- 1242.

54. Chung KT, Wong TY, Wei CL, Huang YW, Lin Y, Tannins and human health: a review. Crit Rev Food Sci Nutr 1998; 38:421464.

55. Raquel FE, Bacterial lipid composition and antimicrobial efficacy of cationic steroid coppounds. Biochemica et Biophysica Acta, 2007; 2500-2509.

56. Okwu DE, Evaluation of chemical composition of medicinal plants belonging to Euphorbiaceae. Pak Vet J 2001; 14:160162.

57. Osadebe PO, Okide GB, Akabogu IC, Study on the anti-diabetic activity of crude methanolic extract of Loranthus micranthus Linn. sourced from five different host trees. J Ethnopharmacology 2004; 95:133-138.

58. Lutterodt GD, Ismail A, Basheer RH, Baharudin HM, Antimicrobial effects of Psidum guajava extracts as one Mechanism of its Antimicrobial action on Escherichia coli and Salmonella typhi. Malaysia Journal Medical Science 1999; 6:17-20.

59. Sule MS, Bichi LA, Atiku MK, Antimicrobial and Preliminary Phytochemical Screening of Guiera senegalensis, Euphorbia lateriflora and Mitracapus scaber. W Afr J Pharmacol Drug Res 2001; 18:12-13.

60. Hutchinson J, Dalziel JM. Flora of West Tropical Africa. London: Crown Agents, 1972.

61. Zeljan M, Marica M, Franz B. Flavonoida of G. senegalensisThin layer Chromatography and Numerical Methods. Croatica Chemica Acta 1998; 71(1):69-79. 